\title{
Individual seabirds show consistent foraging strategies in response to predictable fisheries discards
}

\begin{tabular}{|c|c|}
\hline Journal: & Journal of Avian Biology \\
\hline Manuscript ID: & Draft \\
\hline Wiley - Manuscript type: & Article \\
\hline Date Submitted by the Author: & $\mathrm{n} / \mathrm{a}$ \\
\hline Complete List of Authors: & $\begin{array}{l}\text { Patrick, Samantha; University of Gloucestershire, Biosciences; University of } \\
\text { Oxford, Zoology } \\
\text { Bearhop, S.; University of Exeter, } \\
\text { Bodey, Thomas; University of Exeter, } \\
\text { Grecian, James; University of Glasgow, IBAHCM } \\
\text { Hamer, Keith; University of Leeds, School of Biology } \\
\text { Lee, Janette; CEFAS, } \\
\text { Votier, Stephen; University of Exeter, Environment and Sustainability } \\
\text { Institute }\end{array}$ \\
\hline Keywords: & $\begin{array}{l}\text { intra-individual variability, consistent individual differences, alternative } \\
\text { foraging strategies }\end{array}$ \\
\hline Abstract: & $\begin{array}{l}\text { Current fishing methods often generate huge quantities of dead biomass } \\
\text { that is returned to the sea in the form of discards. This practice produces } \\
\text { readily available clumped resources for scavengers such as seabirds, but in } \\
\text { the face of declining stocks and via policy change, the amount of discards } \\
\text { produced is set to decline in the future. To understand how discards have } \\
\text { influenced seabird foraging in the past and how birds may respond to } \\
\text { future change requires studies examining consistent individual foraging } \\
\text { choices. There is increasing evidence that populations may be composed } \\
\text { of generalist or specialist foragers and this is key to the population's ability } \\
\text { to adapt to change. Here we test for consistent individual foraging } \\
\text { behaviour of northern gannets (Morus bassanus) in relation to fishing } \\
\text { vessels and examine consequences of scavenging behaviour in terms of } \\
\text { foraging effort and body condition. Using a combination of bio-logging } \\
\text { devices (GPS and Time Depth Recorders) with high resolution GPS data } \\
\text { acquired through vessel monitoring systems on fishing boats, we examined } \\
\text { the overlap between birds and fisheries. We found that during repeat } \\
\text { foraging trips in the same breeding season, gannets regularly foraged at } \\
\text { fishing boats but there were clear among individual differences in the } \\
\text { extent of fisheries overlap. Furthermore, we show for the first time that } \\
\text { these differences represent consistent strategies - individual differences in } \\
\text { scavenging were highly repeatable across multiple trips. However, despite } \\
\text { these differences, we found no differences in foraging effort or body } \\
\text { condition between scavengers and non-scavengers. Moreover, scavenging } \\
\text { strategy did not influence diving behaviour or vary by sex. Scavenging on } \\
\text { discards appears to be a strategy employed consistently by a subsection of }\end{array}$ \\
\hline
\end{tabular}


the population, and future work should examine what causes these individual differences, exploring possible demographic and fitness consequences in light of global changes to fish stocks and fisheries management.

SCHOLARONE $^{\text {m }}$

Manuscripts 


\section{Individual seabirds show consistent foraging strategies in response to}

\section{2 predictable fisheries discards}

3

4 Samantha C. Patrick $^{1,2^{*}}$, Stuart Bearhop ${ }^{3}$, Thomas W. Bodey ${ }^{3}$, W. James Grecian ${ }^{4}$, Keith C.

5 Hamer $^{5}$, Janette Lee ${ }^{6}$, and Stephen C. Votier ${ }^{3}$

6

7 1. Bioscience, Francis Close Hall, University of Gloucestershire, GL50 4AZ, UK.

8 2. Department of Zoology, University of Oxford, South Parks Road, Oxford, OX1 3PS, UK.

9 3. University of Exeter, Penryn Campus, Cornwall, TR10 9EZ, UK.

10 4. Institute of Biodiversity, Animal Health \& Comparative Medicine, College of Medical,

11 Veterinary and Life Sciences, University of Glasgow, Glasgow, G12 8QQ, UK

12 5. School of Biology, University of Leeds, Leeds LS2 9JT, UK.

13 6. CEFAS, Pakefield Road, Lowestoft, Suffolk, NR33 0HT, UK.

14

$15 *$ corresponding author: samantha.patrick@liverpool.ac.uk

16

17 
Current fishing extraction methods often generate huge quantities of dead or dying biomass that is returned to the sea in the form of discards. This practice produces a readily available clumped resource for many scavengers such as seabirds, but in the face of declining stocks and via policy change, the amount of discards produced is set to decline in the future. To understand how discards have influenced seabird foraging in the past and how birds may respond to future change requires studies examining consistent individual foraging choices. There is increasing evidence that populations may be made up of generalist or specialist foragers and this is key to the population's ability to adapt to change. Here we test for consistent individual foraging behaviour of northern gannets (Morus bassanus) in relation to fishing vessels and examine consequences of scavenging behaviour in terms of foraging effort and body condition. Using a combination of bird-borne bio-logging devices (GPS and Time Depth Recorders) with high resolution GPS data acquired through vessel monitoring systems on fishing boats, we examined the overlap between birds and fisheries. We found that during repeat foraging trips in the same breeding season, gannets regularly foraged at fishing boats but there were also clear among individual differences in the extent of fisheries overlap. Furthermore, we show for the first time that these differences represent consistent strategies individual differences in scavenging were highly repeatable across multiple trips. However, despite these differences, we found no differences in foraging effort or body condition between scavengers and non-scavengers. Moreover, scavenging strategy did not appear to influence diving behaviour or vary by sex. Scavenging on discards appears to be a strategy employed consistently by a subsection of the population, and future work should examine what causes these individual differences and explore possible demographic and fitness consequences in light of global changes to fish stocks and fisheries management. 
43

44

45

46

47

48

49

50

51

52

53

54

55

56

57

58

59

60

61

62

63

64

65

66

67

68

\section{$\underline{\text { Keywords }}$}

Specialisation, personality, GPS tracking, intra-individual variability, consistent individual differences, alternative foraging strategies, discards, fisheries, seabird

\section{Introduction}

Commercial fisheries have changed the structure and functioning of marine ecosystems worldwide (Lewison et al. 2004, Smith et al. 2011). These changes can lead to cascading effects throughout the ocean, with consequences for many higher predators (Furness 2003, Pikitch 2012). While these effects are often deleterious, such as accidental seabird bycatch (Brothers et al. 1999, Weimerskirch et al. 2000), fisheries also provide an important food subsidy for large numbers of scavengers across the globe, in the form of discarded fish and offal (Furness 2003, Votier et al. 2004a, Bicknell et al. 2013). Foraging on discards allows scavengers, such as some seabirds, to supplement and broaden their diet by utilising prey that would otherwise be unavailable (Furness 2003, Votier et al. 2004a, Bicknell et al. 2013).

Concerns about the parlous states of global fish stocks, as well as the wasteful and potentially deleterious impact of discarding, have led to widespread changes to discarding practices. These changes include an introduction of more selective gears to reduce bycatch, and a policy to retain $100 \%$ of catch (Council of the European Union 2013). Despite the clear benefits of such measures to fish stocks (Catchpole et al. 2005), the ecosystem-wide implications of a discard ban, particularly for seabirds, are more difficult to predict and warrant further study (Bicknell et al. 2013).

Seabirds are well known to forage at fishing vessels, with species of Procellariiformes, Sulidae and Laridae being conspicuous consumers behind trawlers (Garthe et al. 1996, Furness 2003, Bicknell et al. 2013, Votier et al. 2013). While discards create a clumped, easily accessible resource for these species, the uncertain future of this practice emphasises 
69

the need to clarify how such resources are divided among individuals, populations and species (Bicknell et al. 2013). Recent work has highlighted that individuals differ in their attendance at vessels and the quantity of discards they consume (Votier et al. 2010, Granadeiro et al. 2011, Torres et al. 2011, Votier et al. 2013, Granadeiro et al. 2014). This phenomenon may be a manifestation of individuals opportunistically exploiting fishing discards when they encounter them (i.e. they may be opportunistic generalists), or it may be evidence that subsections of the population specialise on discarded fish (i.e. they may be specialists).

The persistence of generalists and specialists in nature is widely attributed to the degree of stability of available resources (Westeberhard 1989). Generalist foragers display greater phenotypic plasticity, which enables them to respond more rapidly to fluctuations in the environment (Westeberhard 1989, Robinson et al. 1996, Svanback \& Schluter 2012). Generalists are thus favoured in unpredictable and unstable environments. However, specialisation can be highly advantageous as individuals can decrease search and handling costs and reduce their niche overlap with other individuals, minimising competition (Bolnick et al. 2003, Araujo et al. 2011). While this strategy may be favoured in stable environments, specialisation strongly contributes to extinction risk if it is coupled with reduced plasticity in behaviour at the population level (Mitter et al. 1988, Biesmeijer et al. 2006).

Foraging specialisations are widespread in seabirds (Votier et al. 2004b, Bearhop et al. 2006, Woo et al. 2008, Patrick et al. 2014), and their prevalence in nature is thought to emerge as a result of the broad-scale predictability in marine resources (Weimerskirch 2007, Scales et al. 2014). Foraging behaviours in seabirds have also evolved in the presence of persistent anthropogenic food sources (McCleery \& Sibly 1986, Annett \& Pierotti 1999, Votier et al. 2004b, Navarro et al. 2009, Navarro et al. 2010, Votier et al. 2010, Granadeiro et al. 2011, 
94 Torres et al. 2011, Oro et al. 2013, Granadeiro et al. 2014), suggesting consistency can

95 develop rapidly in reponse to newly available prey. Furthermore, foraging specialisations may 96 represent consistent individual differences or "personality differences" (Reale et al. 2007) and 97 there is increasing evidence that niche segregation itself may lead to the emergence of such personalities (Bergmuller \& Taborsky 2010). The union between foraging specialisations and animal personality is particularly important as there is strong evidence that personality differences are heritable (e.g. Dingemanse et al. 2002, Sinn et al. 2006) and this heritability

101 has recently been demonstrated in seabirds (Patrick et al. 2013).

103 There is some evidence of among individual differences in the use of discards by seabirds 104 (Votier et al. 2004b, 2010), but it is unclear the extent to which these represent consistent 105 differences in individual tactics. The only previous attempt to quantify the consistency of 106 foraging strategies in terms of at-sea association around fishing vessels found no support for 107 specialisation (Granadeiro et al. 2014), although the study examined behaviour over the 108 Patagonian Shelf where fishing effort is low and patchy (Granadeiro et al. 2011). By contrast, 109 in other parts of the world fishing effort tends to be more intensive and consistent, which 110 could lead to the emergence of consistent individual scavenging tactics. In the Celtic Sea, for 111 example, fishing boats are found at very high density, and tend to be consistent in time and 112 space (Witt \& Godley 2007, Campbell et al. 2014). The intensity and wide-spread 113 distribution of fishing vessels makes this an ideal test of the hypothesis that specialisation is 114 more likely to emerge under stable and predictable conditions.

116 In this study, we use bird-borne GPS loggers and time depth recorders (TDRs) to reconstruct 117 fine-scale foraging behaviour of chick-rearing northern gannets (Morus bassanus) from a 118 single large colony and relate this to fishing vessel activity in the Celtic Sea from the vessel 
119 monitoring system (VMS). Using repeat foraging trips from the same individuals to examine

120 consistent sex-specific and individual differences in seabird-fishery interactions, we test the

121 following hypotheses: (i) Individual gannets differ in the extent to which they overlap with

122 fishing boats; (ii) These differences are consistent over repeat foraging trips; (iii) A subsection

123 of the population accounts for this repeatability, specialising in targeting fishing vessels. We

124 then extend these analyses to assess the costs and benefits to any variation by testing the

125 following predictions: (iv) birds that forage at boats exhibit changes to their foraging

126 behaviour, investing less energy in foraging, and; (v) birds that forage at boats show poorer

127 body condition compared to those that do not.

128

129

Materials and methods

$130 \quad$ Data collection

131 Fieldwork was carried out on Grassholm, Wales, UK $\left(51^{\circ} 43^{\prime} \mathrm{N}, 05^{\circ} 28^{\prime} \mathrm{W}\right)$ during chick-

132 rearing in July and August 2010. Approximately 40,000 pairs of gannets breed here annually

133 and 26 individuals were fitted with i-gotU GPS loggers (Mobile Action Technology; mass

$13430 \mathrm{~g}$ ) and ten birds with an additional G5 time-depth recorder (TDR; CEFAS technology; mass

$1356 \mathrm{~g}$ ). All devices were attached to the central tail feathers using TESA tape (Tesa Tape Inc).

136 GPS loggers were programmed to record locations every two minutes, and TDRs had a

137 recording frequency of $10 \mathrm{~Hz}$ once submerged. 20 birds had usable GPS data (19 of known

138 sex) and of these, 7 birds (6 of known sex) had complete TDR dive data. Capture and

139 handling time of birds was $<10$ minutes. Previous studies have found no effect of larger

140 devices on foraging trip duration (Hamer et al. 2009) and in the present study, no individuals

141 abandoned chicks during the study period and we have no evidence that devices changed

142 birds' foraging behaviour. Blood samples were collected from the tarsal vein of all

143 individuals, under licence from the UK Home Office, for subsequent molecular sexing. 
144 Samples were spun in a centrifuge at 14,000 rpm for approximately 10 minutes to separate red

145 blood cells and plasma before being stored on ice. DNA was extracted from $2 \mathrm{ml}$ of red blood

146 cells using the ammonium acetate protocol based on Bruford et al.(1998). Individuals were

147 sexed using 2550F (Fridolfsson \& Ellegren 1999) and 2757R (Griffiths et al. 1998) primers

148 (K. Griffith, pers. comm; Table S1).

149

\section{$150 \quad$ Fisheries activity}

151 High-resolution data on the location of commercial fishing vessels are available from the

152 vessel monitoring system (VMS). At the time of the study data, were available describing the

153 location, in UK waters, of vessels $>15 \mathrm{~m}$ of all nationalities at a temporal resolution of \pm 2

154 hours. Data from Irish waters included only UK vessels and so were excluded (8\% of all

155 locations; see Table S2 for details of excluded data). The Centre for Environment, Fisheries

156 and Aquaculture Science (CEFAS) conducted VMS data filtering and provided an

157 anonymised output, which was used to calculate measures of fishing activity. A generic

158 speed filter was applied to identify and remove points where boats may not have been actively

159 fishing. This is important because gannets tend not to be attracted to fishing vessels that are

160 either steaming or drifting (Bodey et al. 2014). As vessel locations were available only every

1612 hours, this introduced uncertainty into the interim positions of these boats. While simple

162 straight line or curvilinear interpolation can be employed in such circumstances, its accuracy

163 depends on a number of assumptions that we were not able to test (Torres et al. 2011).

164 Accordingly, we instead used $30 \mathrm{~km}$ buffers (estimated maximum distance a boat could move

165 in two hours) around exact known locations with a two-hour time window, to provide a 166 conservative estimate of vessel location. 
168 Because VMS is restricted to vessels $>15 \mathrm{~m}$ and there may be some Illegal, Unreported and 169 Unregulated fishing, we sought an independent assessment of fisheries interactions. Data 170 collected from small bird-borne cameras (See Votier et al. 2013 for methods) deployed in 1712011 showed that 84/89 (94\%; S. Votier, Unpub. data) of locations known to be with a vessel

172 from photographs were also categorised as overlapping with fisheries using our VMS 173 methods described above. Therefore we can be confident that VMS provides a very accurate 174 representation of gannet/fishery interactions.

175

176

177

178

\section{Analysis}

\section{Overlap between gannets and fisheries}

The spatial positions of individual gannets were extracted from GPS data (hereafter "gannet positions") and overlaid with VMS data to determine the extent of overlap between gannets and fishing vessels. We used three different data sets (Figure 1):

(i) Complete tracks.

As birds may feed throughout foraging trips (Hamer et al. 2009; Figure 1), we first used gannet positions from complete trips (Figure 1b). We removed all points when birds were on the water (this behaviour was identified using a speed threshold of $5 \mathrm{kmh}^{-1}$ ) and positions at night, when birds do not feed (Hamer et al. 2000). We also excluded partial foraging trips and any points within $1 \mathrm{~km}$ of the colony, to avoid times when birds were at the nest.

(ii) Area restricted search zones (ARSZ).

Centrally-placed foraging trips typically include commuting behaviour, where there may be strong spatial and temporal auto-correlation in the data. To overcome such problems, we identified areas of reduced speed and increased turning rate where 
individuals spent prolonged periods (hereafter ARSZ). These zones are strongly associated with increased foraging effort in a number of marine predators, including gannets (Hamer et al. 2009). We identified these areas by calculating residence times at each GPS location along all foraging tracks (Barraquand \& Benhamou 2008). Residence time estimates the amount of time a bird spends in a circle of given radius (here $30 \mathrm{~km}$ ). We favour this method above others (e.g. first-passage time; Pinaud and Weimerskirch. 2005), because in the method we used there is no subjectivity between individual measures, ensuring that individual differences are due to actual behavioural variation and not analytical techniques. These data were available for all birds and we selected GPS locations where the residence time was in the upper quartile, and used these locations as ARSZ. For this analysis, we removed all points when birds

(iii) Dive locations

For 7 birds with simultaneous GPS and TDR data, we interpolated GPS tracks to a resolution of 1 second using a cubic spline interpolation, and matched these temporal data to those from the TDR. Once we had matched the time stamp from the GPS and TDR, we extracted the dive positions from the GPS data (Figure 1d).

212 Across these three sets of data we determined whether or not every gannet position was within

$21330 \mathrm{~km}$ and \pm 2 hours of any fishing vessel based on VMS data. A gannet position was scored 214 as; $0=$ no boats were present or $1=$ at least one boat was present.

215 
217 For each bird, the total number of positions with a boat present per trip was divided by the 218 total number of positions per trip, to give the proportion of time spent at fishing vessels 219 (bounded by zero and one). Individual and sex-specific differences in this response variable 220 were then examined in a general linear mixed model with a Gaussian error structure, with individual bird ID and then sex fitted as a fixed effect in models. While our data could be modelled with a binomial error structure, this weights longer foraging trips more heavily and we did not want this. Instead the proportion of points at fishing vessels approximated well to a Gaussian error structure. We were unable to fit bird ID and sex in the same model due to the nature of these variables. We tested for the significance of effects by using ANOVA comparisons of models with and without bird ID or sex. Fitting bird ID as a fixed effect with sex led to a rank deficient model where we could no estimate all coefficients, so we were constrained to fit each effect in turn.

\section{Are individuals repeatable in their overlap with fisheries?}

231 We estimated individual repeatability (r) in fishery overlap by calculating how much of the

232 variation in time spent at fishing vessels that was explained by individual behaviour. We 233 achieved this by running a general linear mixed model with bird ID as a random effect and no

234 fixed effects (Nakagawa \& Schielzeth 2010; Table 1). This repeatability can be thought of as an average level of specialisation among individuals within the population.

\section{Do individuals differ in the level of specialisation in their use of fishing vessels?}

238 To examine differences in the degree of specialisation at the individual-level, we classified all 239 trips as "with a boat" or "not with a boat" based on the presence of a vessel in an ARSZ. We 240 then calculated the proportion of birds that were always at vessels (specialists on discards), 
241 never at vessels (specialists on natural prey) or a mixture of the two (generalists). This is a

242 metric of intra-individual variability.

\section{Influence of fishery interactions on foraging effort}

245 To determine whether association with fishing vessels influenced foraging effort, we 246 calculated the following metrics: (a) trip duration (hours), (b) proportion of time spent flying

247 during daylight (hours; binomial), (c) maximum distance from colony (km; log transformed to 248 conform to the assumptions of normality; maximum range), and for a sub-sample of 7 birds 249 with dive data: (d) the number (Poisson) and (f) the maximum vertical depth of dives reached 250 per individual dive. These metrics were each fitted as the response variable in a linear mixed 251 model with an estimate of average fisheries overlap and sex as fixed effects and bird ID as a 252 random effect (Table 1). Response variables had a Gaussian error distribution except when 253 stated otherwise. Trip ID was also included as a random effect for maximum vertical depth 254 of dive, as there were multiple dives per trip. Average fisheries overlap was calculated using 255 gannet positions from ARSZ because dive data were available for only a small subset of 256 individuals. The proportion of points with boats present per trip was divided by the total 257 number of points per trip to give a value from 0 (no overlap with vessels) to 1 (all ARSZ 258 overlap with vessels).

259

\section{Influence of fishery interactions on body condition}

261 The maintenance of body condition has important fitness consequences (Velando \& Alonso262 Alvarez 2003), and so we examined whether or not there were differences in the body 263 condition of gannets depending on whether they largely scavenged at fishing vessels or not. 264 Body condition was estimated using a general linear model, with mass as the response and 
265 wing, tarsus and bill as fixed effects. Sex and the average overlap with fisheries were fitted as

266 fixed effects.

267

268 ANOVA comparisons of models with and without terms of interest were used to test the 269 significance of main effects (Table 1). Fixed effects with a significance of $p<0.10$ were 270 maintained in models (Except for individual differences; see above). Analyses were 271 conducted in Matlab (R2009b, Mathworks), R 2.11.1 (R Development Core Team), Free 272 Pascal 1.0.12 and ArcGIS 9.3 (ESRI, USA).

273

274

275

276

277 278 279

280

281

282

283

284 285

\section{Results}

Foraging tracks were obtained for 20 individuals, with three repeat trips from nine individuals, four repeats from eight individuals, five repeats from one individual and seven repeats from two individuals. Fisheries data were available for all foraging trips.

\section{Overlap between gannets and fisheries}

There were strong differences among individuals in the overlap with fisheries, ranging from $4 \%$ to $100 \%$ overlap during a single trip (Table 2; Electronic supplementary material Table S2). These differences in the extent of interaction with vessels were highly repeatable within individuals (measured over a period of 6.14 - 8.36 days), especially at dive sites (differences between individuals: $\mathrm{F}_{6,22}=23.10 ; p<0.001$; Table 2 ; repeatability between individuals: $\mathrm{r}=$ $0.88 \pm 0.12 ; p<0.001 ;$ Table 2; Figure 2) indicating that these differences represent consistent individual strategies. $60 \%$ of birds ( 4 of 6 females; 8 of 14 males) overlapped with boats on all trips and only $10 \%$ of birds (none of 6 females; 2 of 14 males) never overlapped with vessels. $30 \%$ of birds ( 2 of 6 females; 4 of 14 males) had some foraging trips with boats and some without, suggesting that $70 \%$ of our population showed some degree of 
290 specialisation, while $30 \%$ were true generalists. There was no evidence of sex differences in

291 the overlap with fisheries (Table 2).

\section{Influence of fishery interactions on foraging effort}

294 All measures of foraging effort were highly variable between individuals (Table 2). However, 295 overlap with fishing vessels was not a good predictor of trip duration $\left(\chi^{2}{ }_{1}=0.20 ; p=0.65\right.$;

296 Table 2), proportion of time spent flying $\left(\chi_{1}^{2}=0.09 ; p=0.76\right.$; Table 2), maximum range

297 (maximum distance from colony: $\chi^{2}{ }_{1}=3.18 ; p=0.07$; Table 2), nor the number $\left(\chi_{1}^{2}=2.28 ; p\right.$ $298=0.13$; Table 2) or depth of dives $\left(\chi_{1}^{2}=1.94 ; p=0.16\right.$; Table 2). There were no sex 299 differences in trip duration $\left(\chi^{2}{ }_{1}=0.09 ; p=0.78\right.$; Table 2$)$, proportion of time spent flying 300 maximum range $\left(\chi_{1}^{2}=1.39 ; p=0.24\right.$; Table 2$)$, maximum range $\left(\chi^{2}{ }_{1}=1.51 ; p=0.22\right.$; Table $3012)$ nor the number $\left(\chi^{2}{ }_{1}=0.08 ; p=0.77\right.$; Table 2$)$ or depth of dives $\left(\chi^{2}{ }_{1}=2.80 ; p=0.09\right.$; Table 302 2).

303

\section{Influence of fishery interactions on body condition}

305 There was no relationship between body condition and the degree of association with fishing 306 vessels $\left(\mathrm{F}_{5,13}=0.00 ; p=0.96\right)$.

\section{Discussion}

309 In this study, we show that during multiple foraging trips from the same birds, there is repeatable overlap between foraging gannets and fishing vessels. Our results support previous

311 studies suggesting between individual variation in the degree of association between seabirds

312 and fisheries (Votier et al. 2010, Granadeiro et al. 2011, Torres et al. 2011, Granadeiro et al.

313 2014), but importantly we demonstrate that these differences, over 3-7 repeat trips $(6.14-$

3148.36 days), represent consistent individual foraging strategies (i.e. specialisation), with 70\% 
315 of birds being specialists. Foraging repeatability was particularly strong at dive sites (See

316 Bell et al. 2009 for a review of behavioural repeatabilities), which may be related to the fact

317 that this is our most accurate measure of foraging location. We found no evidence of sex

318 differences in the overlap with fishing boats and there was little evidence to suggest that

319 overlap with fisheries results in changes to foraging effort or diving behaviour. These results

320 compliment previous dietary studies (e.g. Annett \& Pierotti 1999, Votier et al. 2004b, Votier

321 et al. 2010) showing individual differences in discard consumption and highlight the 322 importance of individual foraging strategies.

323

324

325

326

327

\section{Individual foraging specialisation at fishing vessels}

Consistent individual diet and foraging strategies are common among seabirds (e.g. Votier et al. 2004b, Bearhop et al. 2006, Patrick et al. 2014). However, to date, they have mainly been reported in natural systems (but see also McCleery \& Sibly 1986, Annett \& Pierotti 1999, Votier et al. 2004, Navarro et al. 2009, Navarro et al. 2010, Votier et al. 2010, Granadeiro et al. 2011, Torres et al. 2011, Oro et al. 2013, Granadeiro et al. 2014) and here we provide support that individual strategies may evolve when birds use anthropogenic resources. Previous work has shown that feeding on discards can be a highly specialised strategy, with consequences for fitness (e.g. Annett \& Pierotti 1999). In this study, we demonstrate that such specialisation in diet is coupled with behavioural specialisation at the individual level: in this population, assuming birds do not differ in encounter with boats by chance, $70 \%$ of birds are behaviourally specialised to foraging with or without fishing boats. Although our data were collected over a single season, previous suggestions that such prey choice (Annett \& Pierotti 1999) and personality-mediated foraging behaviour (Patrick and Weimerskirch 2014; Patrick et al. 2013) could have a genetic basis raise interesting questions about foraging plasticity between years. This leads to the prediction that individuals may demonstrate 
340 limited plasticity potentially constraining an individual's ability to change strategies and

341 future work should focus on the consistency in behaviour over years and the potential

342 selection consequences for subsections of the population undertaking different strategies.

343

344 A key assumption is that VMS data offers an accurate representation of fishing activity in the

345 Celtic Sea. The VMS data only covered vessels $>15 \mathrm{~m}$ during the study period and may

346 therefore have missed interactions with smaller vessels. However, analysis of large numbers

347 of images from gannet-borne cameras reveals that these birds tend only to be attracted to large

348 vessels in the Celtic sea such that this is unlikely to be a shortcoming (Votier et al. 2013).

349 Analysis of camera data almost meant the possibility that gannets may also associate with

350 illegal, unreported and unregulated fisheries is unlikely.

351

352 Sex specific differences in fishery interactions

353 In this study we found no evidence of sex-specific differences in the extent to which gannets

354 associated with fishing vessels. Previous work has shown sex-related differences in

355 scavenging behaviour of seabirds, although this appears to vary among species and over time.

356 For instance, a study on gannets from the same colony in 2006 showed, using stable isotope

357 mixing models, that males consumed a higher proportion of discarded whitefish compared

358 with females (Stauss et al. 2012). In addition, analysis of images from bird-borne digital

359 cameras on gannets in 2011 showed that $80 \%$ of male ARSZ were associated with fishing

360 vessels, whereas this proportion was only 30\% for females (Votier et al. 2013). In contrast,

361 Torres et al. (2011) found no difference in the extent to which male and female white-capped

362 albatrosses Thalassarche steadi interacted with fishing vessels, and the same is true of black-

363 browed albatross T. melanophrys (Patrick \& Weimerskirch 2014). Taken together these

364 results suggest that the degree of attraction to fishing vessels varies not only within but also 
365 among species and populations, highlighting the need for studies into factors influencing

366 variation in sex-specific foraging behaviour over time. For instance, some personality types

367 are more plastic in their behaviour (Dingemanse et al. 2010) and individuals specialising on 368 one type of prey may be more plastic than others.

Does overlap with fishing boats reduce foraging effort?

371 We found little evidence that the overlap with fishing vessels correlated with differences in

372 foraging behaviour. Previous research indicated that gannets feeding more on discards were

373 in poorer condition compared with others during 2006 (Votier et al. 2010), suggesting that the

374 costs and benefits of interactions with fishing vessels may vary with time. We found no 375 evidence to support the hypothesis that foraging at vessels results in fewer dives. However, 376 we were able to collect dive data from only 7 individuals and so while we have many repeat 377 dives per individual, giving us confidence in our within-individual measures, our power to 378 assess between-individual differences is limited. Indeed, Figure 2 suggests that birds 379 foraging naturally may dive more frequently than those feeding at fishing vessels and future 380 work should focus on obtaining more dive data to allow a comparison between individuals in 381 this respect.

\section{Conclusions}

384 Our results indicate that individual differences in the extent to which gannets forage at fishing

385 vessels are consistent over time and therefore may be considered a form of foraging 386 specialisation. The mechanisms underlying these individual strategies and their plasticity are 387 poorly understood but may have population-level implications if subsections of the population 388 are forced to change prey in the face of changes in the availability of discards via reform to 389 the EU Common Fisheries Policy (Bicknell et al. 2013). While we strongly support changes 
390 to current discarding practices, we suggest more attention should be given to the potential loss

391 of behavioural variation from the population, linked to the ability to respond to a drastic

392 changes to the environment. Such effects could have ecosystem-wide consequences and we

393 must ensure the system is resilient to this major change in the way we manage our seas

394 (Diamond \& Beukers-Stewart 2011, Bicknell et al. 2013).

395

396 Acknowledgements

397 Thanks to the RSPB and Greg and Lisa Morgan for access to Grassholm and help in the field

398 with Claudia Stauss, James Waggitt and Dave Evans and logistic support from Tim Brooke

399 (Venturejet). Thanks to Susan Waugh for comments on the manuscript, Kate Griffiths for

400 advice on sexing protocols and Mairi Knight, Jon Ellis and Tony Bicknell for help in the lab.

401 Thanks also to Paul Hewson and Dave Hodgson for statistical advice and Suzanne Neville for

402 assistance in establishing collaboration with CEFAS. Thanks to Jose Granadeiro for useful

403 discussions and to Tim Guilford, Robin Freeman, Holly Kirk and Ben Dean for field and

404 analytical advice and to Cornwallis-Russell writing workshop. Funding was provided by the

405 EU Interreg CHARM III project, NERC (NE/H007199/1 and NE/G001014/1) and the

406 Peninsula Research Institute for Marine Renewable Energy. 
407 Table 1: Summary of analyses conducted in this study. Analyses are grouped as they are in the text and full details of the models are given here.

\begin{tabular}{|c|c|c|c|c|c|}
\hline Group & Analysis & Response & \begin{tabular}{|l|} 
Error \\
Distribution \\
\end{tabular} & Fixed effects & Random effects \\
\hline \multirow[t]{6}{*}{$\begin{array}{l}\text { 1) Overlap with } \\
\text { fisheries }\end{array}$} & $\begin{array}{l}\text { Individual } \\
\text { differences }\end{array}$ & \begin{tabular}{|l|} 
Total trip: Proportion of \\
gannet positions with boat
\end{tabular} & Gaussian & Bird ID / Sex & \\
\hline & & $\begin{array}{l}\text { ARSZ: Proportion of gannet } \\
\text { positions with boat }\end{array}$ & Gaussian & Bird ID / Sex & \\
\hline & & $\begin{array}{l}\text { Dives: Proportion of dives } \\
\text { with boat }\end{array}$ & Gaussian & Bird ID / Sex & \\
\hline & $\begin{array}{l}\text { Individual } \\
\text { repeatability }\end{array}$ & $\begin{array}{l}\text { Total trip: Proportion of } \\
\text { gannet positions with boat }\end{array}$ & Gaussian & & Bird ID \\
\hline & & $\begin{array}{l}\text { ARSZ: Proportion of gannet } \\
\text { positions with boat }\end{array}$ & Gaussian & & Bird ID \\
\hline & & $\begin{array}{l}\text { Dives: Proportion of dives } \\
\text { with boat }\end{array}$ & Gaussian & & Bird ID \\
\hline \multirow[t]{5}{*}{$\begin{array}{l}\text { 2) Foraging } \\
\text { behaviour }\end{array}$} & a) Trip duration & Trip duration & Gaussian & Average fisheries overlap + Sex & Bird ID \\
\hline & $\begin{array}{l}\text { b) \% Time spent } \\
\text { flying }\end{array}$ & $\begin{array}{l}\text { Proportion of time spent } \\
\text { flying }\end{array}$ & Binomial & Average fisheries overlap + Sex & Bird ID \\
\hline & c) Maximum range & Maximum range & Gaussian & Average fisheries overlap + Sex & Bird ID \\
\hline & d) Number dives & Number dives & Poisson & Average fisheries overlap + Sex & Bird ID \\
\hline & $\begin{array}{l}\text { e) Maximum } \\
\text { vertical dive depth }\end{array}$ & Maximum vertical dive depth & Gaussian & Average fisheries overlap + Sex & Bird ID + Trip ID \\
\hline $\begin{array}{l}\text { 3) Body } \\
\text { condition }\end{array}$ & Body Condition & Mass & Gaussian & $\begin{array}{l}\text { Average fisheries overlap + Sex + Wing + } \\
\text { Tarsus + Bill }\end{array}$ & \\
\hline
\end{tabular}


410 Table 2: A summary table of the results from the main models in the paper. The raw data is described and the maximum range of values found in 411 each data set. Results examining individual and sex differences are also given and significant results highlighted in bold and those maintained in 412 the model $(p<0.1)$ in italics.

\begin{tabular}{|c|c|c|c|c|c|c|c|c|c|}
\hline Group & Analysis & Response & \begin{tabular}{|l|} 
No. birds \\
(Sex \\
effect)
\end{tabular} & $\begin{array}{l}\text { No. } \\
\text { trips }\end{array}$ & $\begin{array}{l}\text { No. } \\
\text { data } \\
\text { points }\end{array}$ & $\begin{array}{l}\text { Range } \\
\text { (per trip) }\end{array}$ & Bird ID & $\begin{array}{l}\text { Average } \\
\text { fishing } \\
\text { overlap }\end{array}$ & Sex \\
\hline \multirow{6}{*}{$\begin{array}{l}\text { 1) Overlap } \\
\text { with } \\
\text { fisheries }\end{array}$} & $\begin{array}{l}\text { Individual } \\
\text { differences }\end{array}$ & $\begin{array}{l}\text { Total trip: Proportion of gannet } \\
\text { positions with boat }\end{array}$ & $20(19)$ & 78 & 23988 & $0.04-1.0$ & $\begin{array}{l}F_{19,55}=6.47 \\
p<0.001\end{array}$ & & $\begin{array}{l}\mathrm{F}_{1,70}=0.67 \\
\mathrm{p}=0.41\end{array}$ \\
\hline & & $\begin{array}{l}\text { ARSZ: Proportion of gannet } \\
\text { positions with boat }\end{array}$ & $20(19)$ & 75 & 4279 & $0.00-1.00$ & $\begin{array}{l}F_{19,55}=3.12 ; p< \\
0.001\end{array}$ & & $\begin{array}{l}\mathrm{F}_{1,70}=0.24 \\
\mathrm{p}=0.62\end{array}$ \\
\hline & & $\begin{array}{l}\text { Dives: Proportion of dives with } \\
\text { boat }\end{array}$ & $7(6)$ & 23 & 957 & $0.00-1.00$ & $\begin{array}{l}F_{6,22}=23.10 ; p< \\
0.001\end{array}$ & & $\begin{array}{l}\mathrm{F}_{1,18}=2.72 \\
\mathrm{p}=0.12\end{array}$ \\
\hline & $\begin{array}{l}\text { Individual } \\
\text { repeatability }\end{array}$ & $\begin{array}{l}\text { Total trip: Proportion of gannet } \\
\text { positions with boat }\end{array}$ & 20 & 78 & 23988 & $0.04-1.00$ & $\begin{array}{l}\mathrm{r}=0.60 \pm 0.10 ; \mathrm{p} \\
<0.001\end{array}$ & & \\
\hline & & $\begin{array}{l}\text { ARSZ: Proportion of gannet } \\
\text { positions with boat }\end{array}$ & 20 & 75 & 4279 & $0.00-1.00$ & $\begin{array}{l}r=0.37 \pm 0.13 ; p \\
=0.005\end{array}$ & & \\
\hline & & $\begin{array}{l}\text { Dives: Proportion of dives with } \\
\text { boat }\end{array}$ & 7 & 23 & 957 & $0.00-1.00$ & $\begin{array}{l}r=0.88 \pm 0.12 ; p \\
<0.001 ; \text { Fig. } 2\end{array}$ & & \\
\hline \multirow{5}{*}{$\begin{array}{l}\text { 2) Foraging } \\
\text { behaviour }\end{array}$} & a) Trip duration & Trip duration & $20(19)$ & 75 & 4279 & $\begin{array}{l}2.74- \\
97.27 \mathrm{hrs}\end{array}$ & & $\begin{array}{l}\chi_{1}^{2}=0.20 \\
\mathrm{p}=0.65\end{array}$ & $\begin{array}{l}\chi_{1}^{2}=0.09 \\
p=0.78\end{array}$ \\
\hline & $\begin{array}{l}\text { b) } \% \text { time spent } \\
\text { flying }\end{array}$ & $\begin{array}{l}\text { Proportion of time spent flying } \\
\text { during daylight }\end{array}$ & $20(19)$ & 75 & 4279 & $0-93 \%$ & & $\begin{array}{l}\chi_{1}^{2}=0.09 \\
p=0.76\end{array}$ & $\begin{array}{l}\chi_{1}^{2}=1.39 \\
p=0.24\end{array}$ \\
\hline & c) Maximum range & Maximum range & $20(19)$ & 75 & 4279 & $\begin{array}{l}29.03- \\
653.68 \mathrm{~km}\end{array}$ & 2 & $\begin{array}{l}\chi_{1}^{2}=3.18 \\
p=0.07\end{array}$ & $\begin{array}{l}\chi_{1}^{2}=1.51 \\
\mathrm{p}=0.22\end{array}$ \\
\hline & e) Number dives & Number dives & $7(6)$ & 23 & 957 & $\begin{array}{l}1-130 \\
\text { dives }\end{array}$ & & $\begin{array}{l}\chi_{1}^{2}=2.28 \\
\mathrm{p}=0.13\end{array}$ & $\begin{array}{l}\chi_{1}^{2}=0.08 \\
p=0.77\end{array}$ \\
\hline & $\begin{array}{l}\text { f) Maximum } \\
\text { vertical dive depth }\end{array}$ & Maximum vertical dive depth & $7(6)$ & 23 & 957 & $\begin{array}{l}0.5- \\
22.18 \mathrm{~m}\end{array}$ & & $\begin{array}{l}\chi_{1}^{2}=1.94 \\
p=0.16\end{array}$ & $\begin{array}{l}\chi_{1}^{2}=2.80 \\
p=0.09\end{array}$ \\
\hline $\begin{array}{l}\text { 3) Body } \\
\text { condition }\end{array}$ & Body Condition & Mass & $20(19)$ & NA & NA & & & $\begin{array}{l}\mathrm{F}_{5,13}=0.00 \\
\mathrm{p}=0.96\end{array}$ & $\begin{array}{l}F_{4,14}=3.61 \\
p=0.08\end{array}$ \\
\hline
\end{tabular}


415 Figure 1: Methods used to select data from GPS tracking information to produce estimates of 416 gannet foraging areas. a) Solid circles (White): All recorded GPS locations. This was not 417 used in any analysis but is shown to demonstrate the raw data. Arrows show the direction of 418 movement; b) Solid circles (Green): Complete foraging track: all recorded points shown in (a), filtered to exclude points at night or on the water, when birds do not forage; c) Solid circles (Red): "ARSZ" - points from (b) with a residence time in the upper quartile (see text for methods); d) Solid circles (Yellow): "Dive locations" - points from (b) where dives occurred, extracted from time depth recorder data. In plots b-d all GPS locations are plotted as small black points to show the route taken by the bird. Online version only in colour.

Figure 2: Individual consistency in association with vessels. The number of dives in the presence or absence of fishing vessels for seven individual gannets, across all foraging trips. Pale bars (yellow) show diving when a fishing vessel is nearby and dark bars (blue) show diving in the absence of a fishing vessel. When bars are one colour, this represents an individual that engages in only one strategy. Birds 1-2 dive mainly around vessels, birds $3-4$ have a mixed strategy and birds 5-7 dive mainly away from boats.

Figure 3: Three examples of the overlap between foraging gannets and fisheries over sequential tracks. Points where birds overlapped with fisheries are shown by large circles and

434 straight lines show points where birds and boats did not overlap or excluded points (see methods). Shades show different foraging trips.

a) A bird that has a specialist strategy and shows limited overlap with fishery activity. b) A bird that is also a specialist but overlaps

437 with a fishing vessel throughout repeated trips. c) A bird that has a generalist strategy, with 438 some dives occurring within $30 \mathrm{~km}$ of a fishing vessel and some without a vessel. To 
preserve vessel anonymity, there is no scale or location information on these maps.

\section{$\underline{\text { References }}$}

443

444

445

446

447

448

449

450

451

452

453

454

455

456

457

458

459

460

461

462

463

464

465

466

467

468

469

470

471

472

473

474

475

476

477

478

479

480

481

482

483

484

Annett CA, Pierotti R (1999) Long-term reproductive output in western gulls: Consequences of alternate tactics in diet choice. Ecology 80:288-297

Araujo MS, Bolnick DI, Layman CA (2011) The ecological causes of individual specialisation. Ecol Lett 14:948-958

Barraquand F, Benhamou S (2008) Animal movements in heterogeneous landscapes: Identifying profitable places and homogenous movement bouts Ecology 89:3336-3348

Bearhop S, Phillips RA, McGill R, Cherel Y, Dawson DA, Croxall JP (2006) Stable isotopes indicate sex-specific and long-term individual foraging specialisation in diving seabirds. Marine Ecology-Progress Series 311:157-164

Bell AM, Hankison SJ, Laskowski KL (2009) The repeatability of behaviour: A metaanalysis. Anim Behav 77:771-783

Bergmuller R, Taborsky M (2010) Animal personality due to social niche specialisation. Trends Ecol Evol 25:504-511

Bicknell AWJ, Oro D, Camphuysen K, Votier SC (2013) Potential consequences of discard reform for seabird communities. J Appl Ecol 50:649-658

Biesmeijer JC, Roberts SPM, Reemer M, Ohlemuller Rand others (2006) Parallel declines in pollinators and insect-pollinated plants in britain and the netherlands. Science 313:351-354

Bodey, T.W., Jessopp, M. J. Votier, S.C., Gerritsen, H.D., Cleasby, I.R., Hamer, K.C., Patrick, S.C., Wakefield, E.W., Bearhop, S. Seabird movement reveals the ecological footprint of fishing vessels. Curr. Biol. Vol. 24 (11), pR514-R515.

Bolnick DI, Svanback R, Fordyce JA, Yang LH, Davis JM, Hulsey CD, Forister ML (2003) The ecology of individuals: Incidence and implications of individual specialization. Am Nat 161:1-28

Brothers NP, Cooper J, Lokkeborg S (1999) The incidental catch of seabirds by longline fisheries: Worldwide review and technical guidelines for mitigation, Food and Agriculture Organization of the United Nations, Rome

Bruford MW, Hanotte O, Brookfield JFY, Burke T (1998) Multilocus and singlelocus DNA fingerprinting., Vol. IRL Press, Oxford, UK.

Campbell MS, Stehfest KM, Votier SC, Hall-Spencer JM (2014) Mapping fisheries for marine spatial planning:Gear-specific vessel monitoring system (VMS), marine conservation and offshore renewable energy. Mar Policy 45: 293-300

Catchpole TL, Frid CLJ, Gray TS (2005) Discards in north sea fisheries: Causes, consequences and solutions. Mar Policy 29:421-430

Council of the European Union (2013). Position of the Council at first reading with a view to the adoption of a Regulation of the European Parliament and of the Council on the Common Fisheries Policy, amending Council Regulations (EC) No. 1954/2003 and (EC) No. 1224/2009 and repealing Council Regulations (EC) No. 2371/2002, (EC) No. 639/2004 and Council Decision (EC) No. 2004/585. Interinstitutional File: 2011/0195(COD). Brussels; 2013.

Diamond B, Beukers-Stewart BD (2011) Fisheries discards in the north sea: Waste of resources or a necessary evil? Rev Fish Sci 19:231-245 
485

486

487

488

489

490

491

492

493

494

495

496

497

498

499

500

501

502

503

504

505

506

507

508

509

510

511

512

513

514

515

516

517

518

519

520

521

522

523

524

525

526

527

528

529

530

531

532

533

534
Dingemanse NJ, Both C, Drent PJ, Van Oers K, Van Noordwijk AJ (2002) Repeatability and heritability of exploratory behaviour in great tits from the wild. Anim Behav 64:929938

Dingemanse, N. J., Kazem, A. J., Réale, D., \& Wright, J. (2010). Behavioural reaction norms: animal personality meets individual plasticity. Trends in Ecology \& Evolution, 25(2), 81-89.

Fridolfsson AK, Ellegren H (1999) A simple and universal method for molecular sexing of non-ratite birds. J Avian Biol 30:116-121

Furness RW (2003) Impacts of fisheries on seabird communities. Sci Mar 67:33-45

Garthe S, Camphuysen CJ, Furness RW (1996) Amounts of discards by commercial fisheries and their significance as food for seabirds in the north sea. Marine Ecology-Progress Series 136:1-11

Granadeiro JP, Brickle P, Catry P (2014) Do individual seabirds specialize in fisheries' waste? The case of black-browed albatrosses foraging over the Patagonian shelf. Anim Conserv 17:19-26

Granadeiro JP, Phillips RA, Brickle P, Catry P (2011) Albatrosses following fishing vessels: How badly hooked are they on an easy meal? PLoS One 6

Griffiths R, Double MC, Orr K, Dawson RJG (1998) A DNA test to sex most birds. Mol Ecol 7:1071-1075

Hamer KC, Humphreys EM, Magalhaes MC, Garthe Sand others (2009) Fine-scale foraging behaviour of a medium-ranging marine predator. J Anim Ecol 78:880-889

Hamer KC, Phillips RA, Wanless S, Harris MP, Wood AG (2000) Foraging ranges, diets and feeding locations of gannets morus bassanus in the north sea: Evidence from satellite telemetry. Marine Ecology-Progress Series 200:257-264

Lewison RL, Crowder LB, Read AJ, Freeman SA (2004) Understanding impacts of fisheries bycatch on marine megafauna. Trends Ecol Evol 19:598-604

McCleery RH, Sibly RM (1986) Feeding specialization and preference in herring-gulls. J Anim Ecol 55:245-259

Mitter C, Farrell B, Wiegmann B (1988) The phylogenetic study of adaptive zones - has phytophagy promoted insect diversification. Am Nat 132:107-128

Nakagawa S, Schielzeth H (2010) Repeatability for gaussian and non-gaussian data: A practical guide for biologists. Biological Reviews 85:935-956

Navarro J, Louzao M, Igual JM, Oro Dand others (2009) Seasonal changes in the diet of a critically endangered seabird and the importance of trawling discards. Marine Biology $156: 2571-2578$

Navarro J, Oro D, Bertolero A, Genovart M, Delgado A, Forero MG (2010) Age and sexual differences in the exploitation of two anthropogenic food resources for an opportunistic seabird. Marine Biology 157:2453-2459

Oro D, Genovart M, Tavecchia G, Fowler MS, Martinez-Abrain A (2013) Ecological and evolutionary implications of food subsidies from humans. Ecol Lett 16:1501-1514

Patrick SC, Bearhop S, Gremillet D, Lescroel Aand others (2014) Individual differences in searching behaviour and spatial foraging consistency in a central place marine predator. Oikos 123:33-40

Patrick SC, Charmantier A, Weimerskirch H (2013) Differences in boldness are repeatable and heritable in a long-lived marine predator. Ecol Evol 3:4291-4299

Patrick SC, Weimerskirch H (2014) Personality, foraging and fitness consequences in a long lived seabird. PLoS One 9(2): e87269.

Pikitch EK (2012) The risks of overfishing. Science 338:474-475

Pinaud, D. \& Weimerskirch, H. (2005) Scale-dependant habitat use in a long-ranging central

place predator. Journal of Animal Ecology 74: 852-863 
Reale D, Reader SM, Sol D, McDougall PT, Dingemanse NJ (2007) Integrating animal temperament within ecology and evolution. Biological Reviews 82:291-318

Robinson BW, Wilson DS, Shea GO (1996) Trade-offs of ecological specialization: An intraspecific comparison of pumpkinseed sunfish phenotypes. Ecology 77:170-178

Scales, K.L., Miller, P.I., Embling, C.B., Ingram, S.N., Pirotta, E. \&

Votier, S.C. (2014) Mesoscale fronts as foraging habitats: composite

front mapping reveals oceanographic drivers of habitat use for a pelagic

seabird. Journal of the Royal Society Interface, 11, 20140679.

Sinn DL, Apiolaza LA, Moltschaniwskyj NA (2006) Heritability and fitness-related consequences of squid personality traits. J Evol Biol 19:1437-1447

Smith ADM, Brown CJ, Bulman CM, Fulton EAand others (2011) Impacts of fishing lowtrophic level species on marine ecosystems. Science 333:1147-1150

Stauss C, Bearhop S, Bodey TW, Garthe Sand others (2012) Sex-specific foraging behaviour in northern gannets morus bassanus: Incidence and implications. Marine Ecology Progress Series 457:151-162

Svanback R, Schluter D (2012) Niche specialization influences adaptive phenotypic plasticity in the threespine stickleback. Am Nat 180:50-59

Torres LG, Thompson DR, Bearhop S, Votier S, Taylor GA, Sagar PM, Robertson BC (2011) White-capped albatrosses alter fine-scale foraging behavior patterns when associated with fishing vessels. Marine Ecology-Progress Series 428:289-301

Velando A, Alonso-Alvarez C (2003) Differential body condition regulation by males and females in response to experimental manipulations of brood size and parental effort in the blue-footed booby. J Anim Ecol 72:846-856

Votier SC, Furness RW, Bearhop S, Crane JE and others (2004a) Changes in fisheries discard rates and seabird communities. Nature 427:727-730

Votier, S.C., Bearhop, S., Ratcliffe, N. \& Furness, R.W. (2004b) Reproductive consequences for great skuas specializing as seabird predators. Condor, 106, 275-287.

Votier SC, Bearhop S, Witt MJ, Inger R, Thompson D, Newton J (2010) Individual responses of seabirds to commercial fisheries revealed using gps tracking, stable isotopes and vessel monitoring systems. J Appl Ecol 47:487-497

Votier SC, Bicknell A, Cox SL, Scales KL, Patrick SC (2013) A bird's eye view of discard reforms: Bird-borne cameras reveal seabird/fishery interactions. Plos One 8

Weimerskirch H (2007) Are seabirds foraging for unpredictable resources? Deep-Sea Research Part Ii-Topical Studies in Oceanography 54:211-223

Weimerskirch H, Capdeville D, Duhamel G (2000) Factors affecting the number and mortality of seabirds attending trawlers and long-liners in the kerguelen area. Polar Biol 23:236-249

Westeberhard MJ (1989) Phenotypic plasticity and the origins of diversity. Annual Review of Ecology and Systematics 20:249-278

Witt MJ, Godley BJ (2007) A Step Towards Seascape Scale Conservation: Using Vessel Monitoring Systems (VMS) to Map Fishing Activity. PLoS ONE 2(10): e1111. doi:10.1371/journal.pone.0001111

Woo KJ, Elliott KH, Davidson M, Gaston AJ, Davoren GK (2008) Individual specialization in diet by a generalist marine predator reflects specialization in foraging behaviour. $\mathrm{J}$ Anim Ecol 77:1082-1091 

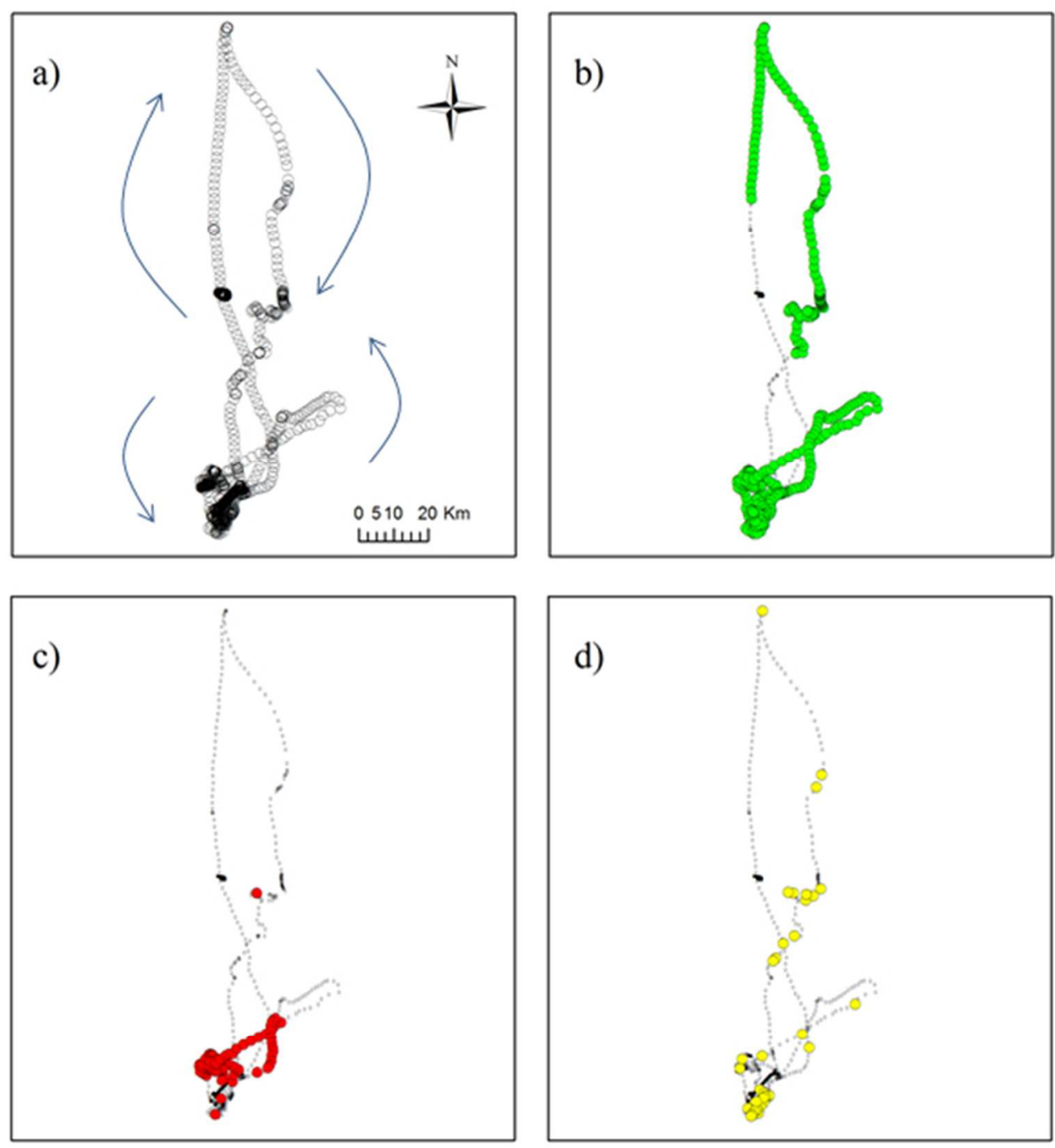

$157 \times 167 \mathrm{~mm}(96 \times 96 \mathrm{DPI})$ 


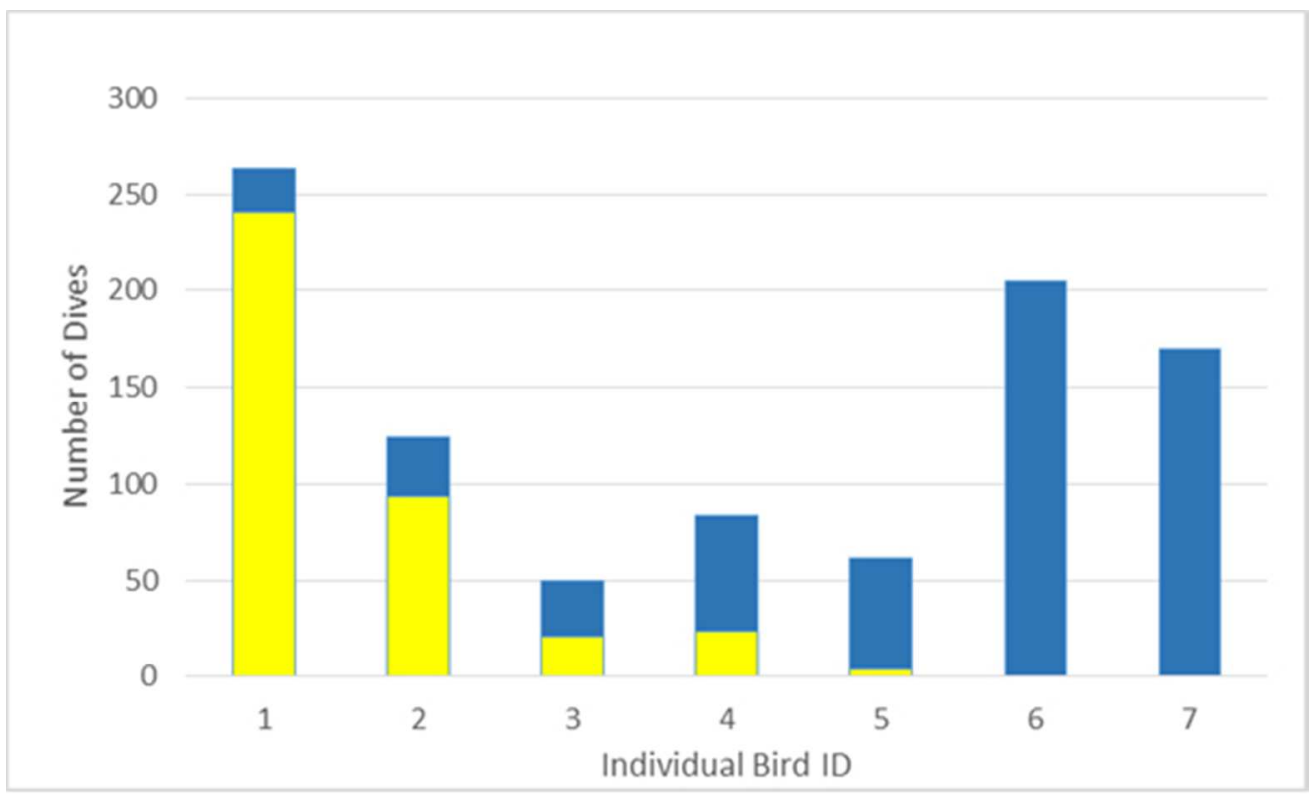

$159 \times 96 \mathrm{~mm}(96 \times 96 \mathrm{DPI})$ 

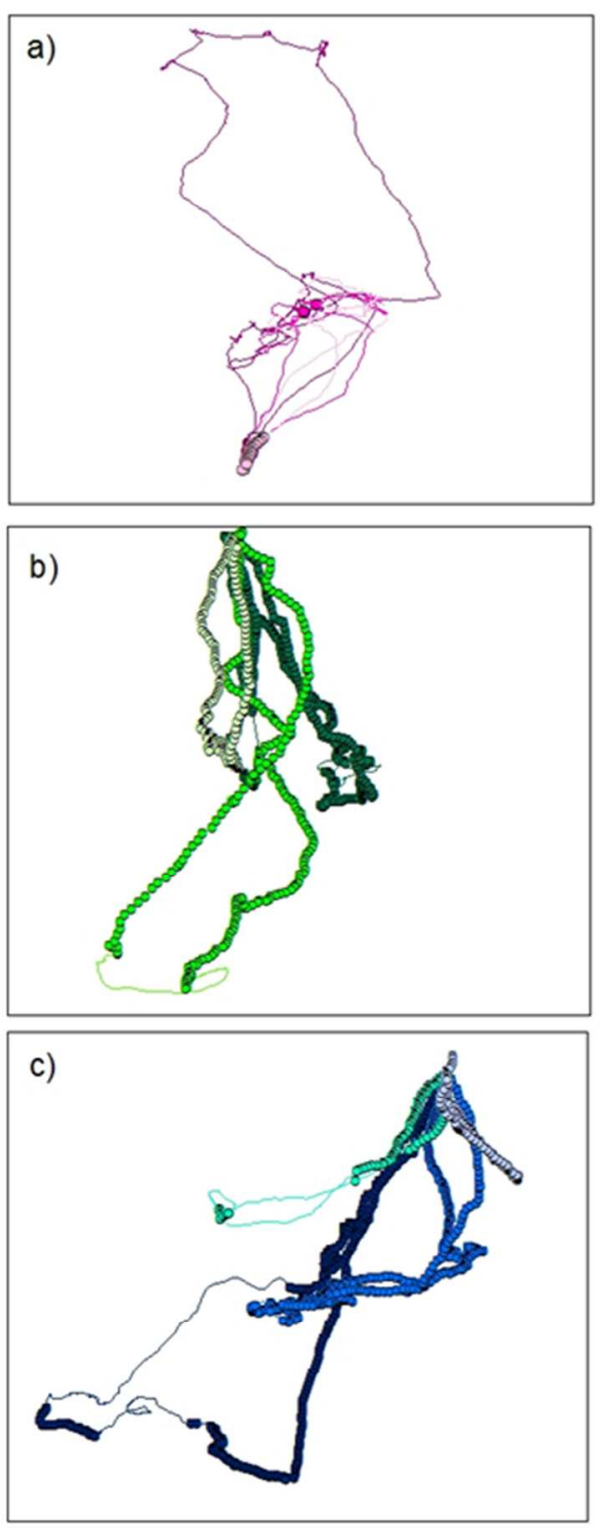

$105 \times 226 \mathrm{~mm}(96 \times 96$ DPI $)$ 


\section{$1 \quad$ Electronic supplementary material}

\section{Methods}

3 Table S1. The conditions and reagents for sexing individual gannets (K. Griffiths Pers.

4 Comm.)

\begin{tabular}{|c|c|}
\hline Primers & $\begin{array}{l}\text { 2550F 5' GTT ACT GAT TCG TCT ACG AGA -3' } \\
\text { 2757R 5' AAT TCC CCT TTT ATT GAT CCA TC -3' }\end{array}$ \\
\hline PCR reagents & $\begin{array}{l}\text { For each 10ul } \\
\text { 2ul DNA }(10-100 \mathrm{ng} / \mathrm{ul}) \\
\text { 1ul Qiagen Buffer } \\
\text { 1ul Qiagen } \mathrm{MgCl} 2 \\
0.2 \mathrm{ul} \text { Qiagen ready mixed dNTP } \\
0.1 \mathrm{ul} \text { Qiagen taq } \\
0.124 \mathrm{ul} 2550 \mathrm{~F} \\
0.116 \text { ul } 2757 \mathrm{R} \\
\text { water to make up to } 10 \mathrm{ul}(5.46 \mathrm{ul})\end{array}$ \\
\hline PCR profile & $\begin{array}{l}94^{\prime} \mathrm{C} \text { for } 2 \mathrm{mins} \\
53^{\prime} \mathrm{C} \text { for } 1 \mathrm{~min} \\
72^{\prime} \mathrm{C} \text { for } 1 \mathrm{~min} \times 30 \text { cycles } \\
94^{\prime} \mathrm{C} \text { for } 45 \mathrm{secs} \\
49^{\prime} \mathrm{C} \text { for } 1 \mathrm{~min} \\
72^{\prime} \mathrm{C} \text { for } 5 \mathrm{mins} \\
12^{\prime} \mathrm{C} \text { pause }\end{array}$ \\
\hline Gel & $2 \%$ agarose with TDE, $1 \mathrm{~h} 30$ mins, 110 volts, $110 \mathrm{~A}$. \\
\hline
\end{tabular}




\section{Analysing the overlap between fisheries and gannet locations.}

8 Table S2: GPS data excluded from the analysis as it was outside the study area.

9

\section{Modelling the overlap between gannets and fisheries}

11 Gannets $=20$

$12 \quad$ Trips $=78$

13 Total GPS Points $(\mathrm{p})=23988$

$\underline{\text { Step } 1}$

16 For every point, $\mathrm{p} \rightarrow$ Measure distance to every fishing boat $(\mathrm{m})$

21 Output $=$ Overlap score for all 23,988 GPS positions

\section{$\underline{\text { Step } 2}$}


27 These two steps were repeated on restricted data sets including only GPS positions where the

28 residence time was in the upper quartile $(\mathrm{p}=4279$ positions $)$ or exact dive locations $(\mathrm{p}=957$

29 positions). 